\title{
Mitochondrial phylogeny and phylogeography of East African squeaker catfishes (Siluriformes: Synodontis) Stephan Koblmüller ${ }^{1}$, Christian Sturmbauer ${ }^{1}$, Erik Verheyen ${ }^{2}$, Axel Meyer ${ }^{3}$ and Walter Salzburger*3
}

\author{
Address: ${ }^{1}$ Department of Zoology, Karl-Franzens-University Graz, Universitätsplatz 2, 8010 Graz, Austria, ${ }^{2}$ Vertebrate Department, Royal Belgian \\ Institute of Natural Sciences, 1000 Brussels, Belgium and ${ }^{3}$ Lehrstuhl für Zoologie und Evolutionsbiologie, Department of Biology, University of \\ Konstanz, 78467 Konstanz, Germany \\ Email: Stephan Koblmüller - stephan.koblmueller@uni-graz.at; Christian Sturmbauer - christian.sturmbauer@uni-graz.at; \\ Erik Verheyen - erik.verheyen@naturalsciences.be; Axel Meyer - axel.meyer@uni-konstanz.de; Walter Salzburger* - walter.salzburger@uni- \\ konstanz.de \\ * Corresponding author
}

Published: 19 June 2006

BMC Evolutionary Biology 2006, 6:49 doi:10.1186/147/-2148-6-49

This article is available from: http://www.biomedcentral.com/I47I-2/48/6/49

(c) 2006 Koblmüller et al; licensee BioMed Central Ltd.

This is an Open Access article distributed under the terms of the Creative Commons Attribution License (http://creativecommons.org/licenses/by/2.0), which permits unrestricted use, distribution, and reproduction in any medium, provided the original work is properly cited.
Received: 10 April 2006

Accepted: 19 June 2006

\begin{abstract}
Background: Squeaker catfishes (Pisces, Mochokidae, Synodontis) are widely distributed throughout Africa and inhabit a biogeographic range similar to that of the exceptionally diverse cichlid fishes, including the three East African Great Lakes and their surrounding rivers. Since squeaker catfishes also prefer the same types of habitats as many of the cichlid species, we hypothesized that the East African Synodontis species provide an excellent model group for comparative evolutionary and phylogeographic analyses.

Results: Our analyses reveal the existence of six major lineages of Synodontis in East Africa that diversified about 20 MYA from a Central and/or West African ancestor. The six lineages show a clear geographic patterning. Two lineages are endemic to Lake Tanganyika (plus one non-endemic representative), and these are the only two Synodontis lineages that diversified further into a small array of species. One of these species is the cuckoo catfish (S. multipunctatus), a unique brood parasite of mouthbrooding haplochromine cichlids, which seems to have evolved in parallel with the radiation of its cichlid host lineage, the Tropheini. We also detect an accelerated rate of molecular evolution in S. multipunctatus, which might be the consequence of co-evolutionary dynamics.

Conclusion: We conclude that the ancestral lineage of today's East African squeaker catfish fauna has colonized the area before the Great Lakes have formed. This ancestor diversified rapidly into at least six lineages that inhabit lakes and rivers in East Africa. Lake Tanganyika is the only lake harboring a small species flock of squeaker catfishes.
\end{abstract}

\section{Background}

The Great Lakes in the East African Rift Valley (Fig. 1a) are home to an exceptionally diverse ichthyofauna [1-4]. The most famous elements of the lakes' faunas are the cichlid fishes that have formed species flocks of an unparalleled species-richness and degree of eco-morphological and behavioral complexity $[1,5,6]$. It has been estimated that almost 1,800 cichlid species inhabit Lakes Tanganyika, 

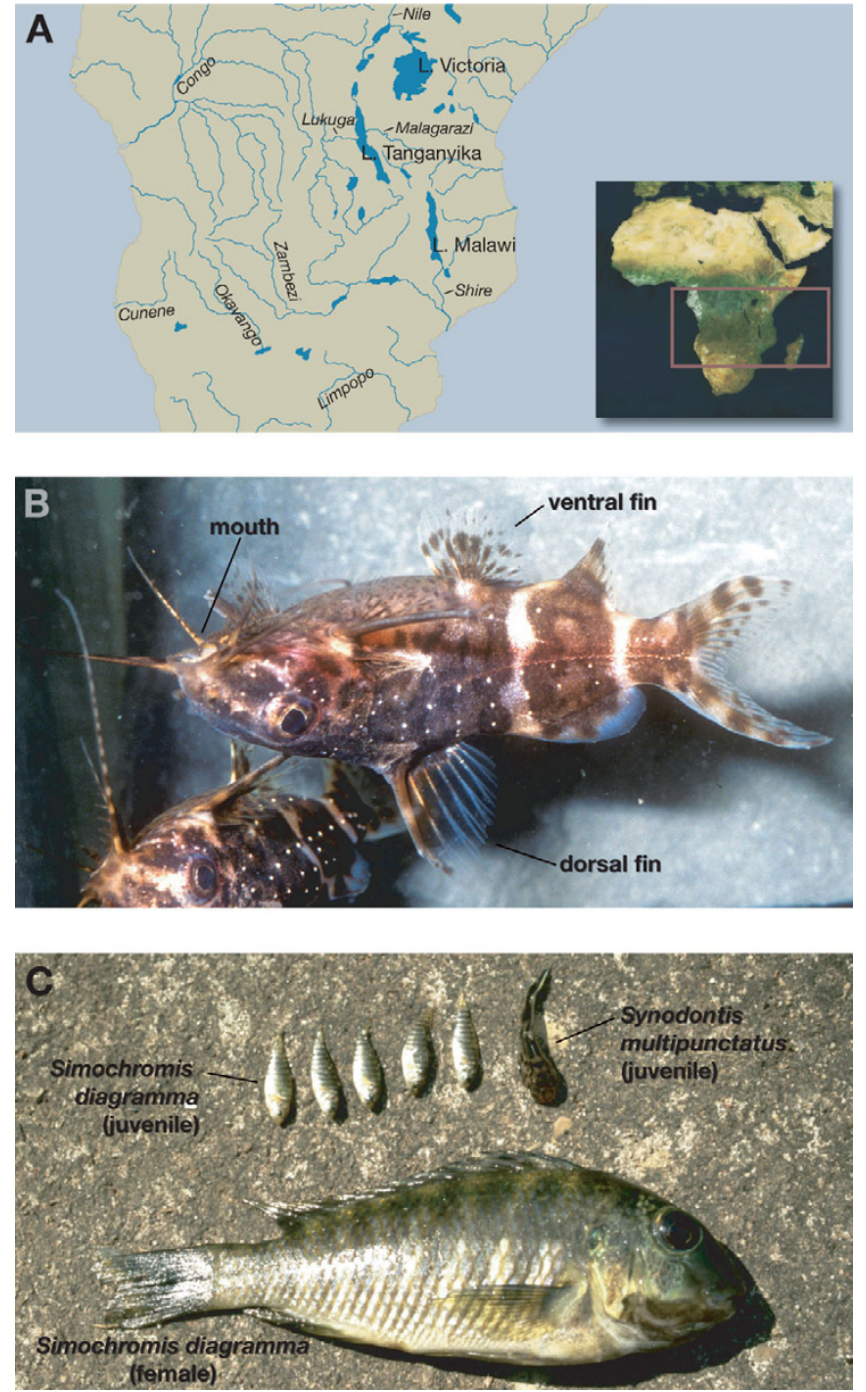

\section{Figure I}

The squeaker catfishes (Synodontis) in East Africa. (a) Map of southern and eastern Africa showingthe Great Lakes in East Africa and the main river systems in thearea. (b) The upside-down catfish (S. nigriventris) is characterized by its inverse swimming posture. Photo courtesy of E. Schraml. (c) The cuckoo catfish(S. multipunctatus) from Lake Tanganyika is a brood parasiteof mouthbrooding haplochromine cichlids. Here, the mouth-content ofa breeding female of Simochromis diagramma is shown: Wefound five larvae of S. diagramma plus one larger cuckoocatfish larvae (Photo: W. Salzburger).

Malawi and Victoria [7,8] and that these lake endemic species are likely to have evolved in the last few millions or as recently as the last thousands of years only [9-12]. It is, thus, not surprising that the cichlid species flocks from the East African Great Lakes have received considerable attention as model systems for the study of adaptive radiation and explosive speciation $[6,13,14]$.
The family Cichlidae is, however, just one of several families of freshwater fishes that inhabit the East African Great Lakes $[1,15]$. In Lake Tanganyika, the oldest lake in East Africa, more than 100 non-cichlid fish species in at least twenty families are recognized, about half of the species being endemic $[1,16,17]$ (Table 1$)$. Interestingly, all Tanganyikan fish families are known to also occur in the Congo River basin that is definitely older and holds a much larger number of fish families than any of the East African water-bodies [15,18]. An initially West African to Central African origin has therefore been proposed for the East African representatives of many of these families [18]. So far, such a scenario has only been confirmed with phylogenetic analyses for the Cichlidae [9,12,19-22], and Clupeidae (Wilson \& Meyer, unpublished), while the Clariidae seem to have colonized Africa from the Arabian plate [23]. Eleven non-cichlid families with about 50 species have been described for Lake Malawi. Only one of these families is not represented in lakes Tanganyika and Victoria: A single anguillid species, the African mottled eel (Anguilla bengalensis labiata), migrates to the area of Lake Malawi via the Zambezi and Shire River. In Lake Victoria, representatives of thirteen non-cichlid fish families are known, two of which were introduced only recently. All other families are also found in Lake Tanganyika (Table 1). Aside of the Cichlidae, nine other families are known to live in all three Great Lakes: Bagridae, Characidae, Clariidae, Cyprinidae, Cyprinodontidae, Mastacembalidae, Mochokidae, Mormyridae, and Protopteridae.

We were interested in the phylogeny and phylogeography of one genus of the catfish family Mochokidae, the squeaker catfishes (Synodontis), in East Africa. With about 190 species assigned to ten genera, the siluriform family Mochokidae is endemic to the African continent where these fishes inhabit freshwaters from small creeks to large streams and from small ponds to large lakes. The genus Synodontis Cuvier, 1816 (including the monotypic genera Brachysynodontis and Hemisynodontis) comprises about 120 species, and is the most species-rich and widespread genus of the Mochokidae. Synodontis species are found throughout Africa, except in the southernmost parts and the Maghreb, although most species occur in Central and West Africa [24]. They are called "squeakers" (also by many local tribes), because of the noise they produce when taken out of the water. Some larger Synodontis species are important food resources. Other species are traded as ornamental fish due to their coloration and because of the interesting behavior of some of the species. The upside-down catfishes ( $S$. contractus, $S$. nigriventris), for example, show an inverse swimming posture (Fig. 1b). Even more bizarre is probably the brood parasitic cuckoo catfish from Lake Tanganyika (S. multipunctatus) that cedes its eggs among those of spawning mouthbrooding cichlids; the female cichlid inadvertently takes up the cat- 
Table I: Freshwater fish families in the East African Great Lakes Victoria, Malawi and Tanganyika (according to refs. [I,I6,I7] and http://www.fishbase.org)

\begin{tabular}{|c|c|c|c|}
\hline fish family & Lake Victoria & Lake Malawi & Lake Tanganyika \\
\hline Amphiliidae & & $\sqrt{ }$ & $\sqrt{ }$ \\
\hline Anabantidae & $\sqrt{ }$ & & $\sqrt{ }$ \\
\hline Anguillidae & & $\sqrt{ }$ & \\
\hline Bagridae & $\sqrt{ }$ & $\sqrt{ }$ & $\sqrt{ }$ \\
\hline Centrarchidae & $\sqrt{*}$ & & \\
\hline Centropomidae & $\sqrt{ } *$ & & $\sqrt{ }$ \\
\hline Characidae & $\sqrt{ }$ & $\sqrt{ }$ & $\sqrt{ }$ \\
\hline Cichlidae & $\sqrt{ }$ & $\sqrt{ }$ & $\sqrt{ }$ \\
\hline Citharinidae & & & $\sqrt{ }$ \\
\hline Clariidae & $\sqrt{ }$ & $\sqrt{ }$ & $\sqrt{ }$ \\
\hline Clupeidae & & & $\sqrt{ }$ \\
\hline Cyprinidae & $\sqrt{ }$ & $\sqrt{ }$ & $\sqrt{ }$ \\
\hline Cyprinodontidae & $\sqrt{ }$ & $\sqrt{ }$ & $\sqrt{ }$ \\
\hline Kneriidae & & & $\sqrt{ }$ \\
\hline Malapteruridae & & & $\sqrt{ }$ \\
\hline Mastacembalidae & $\sqrt{ }$ & $\sqrt{ }$ & $\sqrt{ }$ \\
\hline Mochokidae & $\sqrt{ }$ & $\sqrt{ }$ & $\sqrt{ }$ \\
\hline Mormyridae & $\sqrt{ }$ & $\sqrt{ }$ & $\sqrt{ }$ \\
\hline Polypteridae & & & $\sqrt{ }$ \\
\hline Protopteridae & $\sqrt{ }$ & $\sqrt{ }$ & $\sqrt{ }$ \\
\hline Schilbeidae & $\sqrt{ }$ & & $\sqrt{ }$ \\
\hline Tetraodontidae & & & $\sqrt{ }$ \\
\hline
\end{tabular}

*introduced

fish-eggs into her buccal cavity, together with her own eggs, where the young catfishes nourish on the cichlid larvae (Fig. 1c) [25].

Our interest in the East African Synodontis was founded on several reasons: Firstly, the Mochokidae are abundant in all three East African Great Lakes and are, as a consequence, an ideal system for comparative phylogenetic and phylogeographic analyses with the existing data on cichlid fishes. Secondly, of the nine non-cichlid families common to the three East African Great Lakes, the Mochokidae show the closest overlap in habitat in comparison to cichlids, in that they occur primarily in the littoral and sub-littoral zone $[1,16]$. Thirdly, among the two East African mochokid genera, Synodontis is more species rich as compared to Chiloglanis, particularly in Lake Tanganyika, where seven species of Synodontis have been described. Finally, most Synodontis species can be considered as euryphagous, which enables them to cope with seasonal changes in food abundance and habitat change $[26,27]$. Their feeding regime broadens their food niche and gives them a better ability to colonize different habitats as compared to more specialized fish species such as many lakeadapted cichlids. Thus, their colonization routes in East Africa should be good indicators of fish-accessible waterways in that region over evolutionary time spans.

In order to obtain a better understanding of the evolution, diversity and phylogeography of East African squeaker cat- fish, we aimed to reconstruct the phylogeny of East African Synodontis with special emphasis on the sequence and timing of colonization events of the East African Great Lakes Tanganyika, Malawi and Victoria, and the evolution of "cuckooing" behavior in Lake Tanganyika. Therefore, we sequenced a portion of about $900 \mathrm{bp}$ of the mitochondrial genome of 21 species of the genus Synodontis and the outgroup taxa Microsynodontis batesii and Chiloglanis sp. We included all but one described, plus one, until now, undescribed, species from Lake Tanganyika, the single described Lake Malawi Synodontis, one of the two species occurring in Lake Victoria, two species from East and South African river systems, as well as eleven representatives of Central and West African species (Table 2).

\section{Results}

For this study, we analyzed $407 \mathrm{bp}$ of the mitochondrial control region of 94 specimens and $426 \mathrm{bp}$ of the NADH dehydrogenase subunit 6 gene (ND6) of 52 specimens (including the outgroup taxa). The likelihood mapping analysis yielded a fraction of $89.4 \%$ fully resolved quartets for the total combined data set (Fig. 2a), and $88.7 \%$ fully resolved quartets for the subset including the East African taxa only (Fig. 2b), indicating a fairly strong phylogenetic signal in both data sets. Within the genus Synodontis, pairwise distances (uncorrected p-distances) ranged up to $33.3 \%$ (S. shoutedeni versus S. multipunctatus) in the control region and up to $11.5 \%$ (S. granulosus versus $S$. robertsi) in the ND6 gene segment. The largest uncorrected p- 
Table 2: List of specimens used for this study

\begin{tabular}{|c|c|c|c|c|c|c|}
\hline \multirow{2}{*}{$\begin{array}{l}\text { Taxon } \\
\text { Synodontis njassae }\end{array}$} & \multirow{2}{*}{$\begin{array}{l}\text { origin* } \\
\text { EA (LM) }\end{array}$} & \multirow{2}{*}{$\begin{array}{c}\text { sample locality } \\
\text { M'bamba Bay }\end{array}$} & \multirow{2}{*}{$\frac{\text { collector** }^{* *}}{\mathrm{EV}}$} & \multirow{2}{*}{\begin{tabular}{|c|} 
Taxon ID \\
MbBay (1995)
\end{tabular}} & \multicolumn{2}{|c|}{$\begin{array}{c}\text { GenBank acc. nr. CR/ } \\
\text { ND6 }\end{array}$} \\
\hline & & & & & DQ663012 & DQ663077 \\
\hline & & & EV & Mst45 (1995) & DQ663023 & - \\
\hline & & & EV & M56M5 (1995) & DQ663007 & DQ663070 \\
\hline & & & EV & M5336 (1995) & DQ663005 & DQ663068 \\
\hline & & & EV & M5350 (1995) & $\overline{\mathrm{DQ} 663006}$ & DQ663069 \\
\hline & & & EV & M7043 (1995) & DO663008 & DQ66307I \\
\hline & & & EV & M9008 (1995) & $\overline{\mathrm{DQ} 663009}$ & DQ663072 \\
\hline & & & EV & M9016 (1995) & DQ663022 & - \\
\hline & & & EV & M9043 (1995) & DQ663010 & DQ663073 \\
\hline & & & EV & M9076 (1995) & - & DQ663074 \\
\hline & & & $\mathrm{EV}$ & M9092 (1995) & DQ663011 & DQ663075 \\
\hline & & & EV & M9096 (1995) & $\overline{D Q 663024}$ & - \\
\hline & & & EV & T995 (1995) & DQ663025 & - \\
\hline \multirow[t]{2}{*}{ Synodontis victoriae } & EA (LV, LK, M) & Kisumu, LV & WS & $5 i 8 a(2004)$ & DQ663013 & DQ663059 \\
\hline & & Kisumu, LV & WS & $5 \mathrm{i} 8 \mathrm{~b}(2004)$ & DQ663014 & DQ663060 \\
\hline \multirow[t]{13}{*}{ Synodontis dhonti } & $\mathrm{EA}(\mathrm{LT})$ & Tanganyika Lodge & SK, CS & 3698 & DQ662994 & - \\
\hline & & Kasakalawe Lodge & SK, CS & 3708 & DQ662995 & - \\
\hline & & Kasakalawe Lodge & SK, CS & 3709 & $\overline{\mathrm{DQ} 662996}$ & - \\
\hline & & Chituta Bay & SK, CS & 3736 & DQ662997 & DQ663056 \\
\hline & & Mtondwe Island & SK, CS & 3738 & $\overline{D Q 662998}$ & - \\
\hline & & Katoto & SK, CS & 3771 & DO662999 & - \\
\hline & & Kasakalawe & SK, CS & 3777 & DQ663000 & DQ663057 \\
\hline & & Kasakalawe & SK, CS & 3778 & $\overline{\mathrm{DQ} 663001}$ & - \\
\hline & & Kalambo Lodge & SK, CS & 4535 & DQ663002 & - \\
\hline & & Chituta Bay & TV & 4536 & DQ663003 & - \\
\hline & & Chituta Bay & TV & 4537 & DQ663004 & - \\
\hline & & Ulwile Island & EV & TB 127 & DQ663019 & DQ663065 \\
\hline & & Ulwile Island & EV & TB 128 & DQ663020 & DQ663066 \\
\hline \multirow[t]{2}{*}{ Synodontis granulosus } & $\mathrm{EA}(\mathrm{LT})$ & Chituta Bay & SK, CS & 3735 & $\overrightarrow{D Q 662961}$ & - \\
\hline & & Mtondwe Island & SK, CS & 3773 & DQ662962 & DQ663053 \\
\hline \multirow[t]{17}{*}{ Synodontis multipunctatus } & $\mathrm{EA}(\mathrm{LT})$ & Muzumwa & SK, CS & 3635 & DQ662963 & DQ663046 \\
\hline & & Kalambo Lodge & SK, CS & 3696 & DQ662964 & - \\
\hline & & south of Kalambo & SK, CS & 3697 & DQ662965 & - \\
\hline & & Mpulungu & SK, CS & 3712 & DQ662968 & - \\
\hline & & Mpulungu & SK, CS & 3714 & DQ662969 & - \\
\hline & & Mpulungu & SK, CS & 3715 & DQ662966 & - \\
\hline & & Mpulungu & SK, CS & 3716 & $\overline{D Q 662967}$ & - \\
\hline & & Kasakalawe & SK, CS & 3737 & DO662970 & - \\
\hline & & ?*** & SK, CS & 3739 & DQ662971 & DQ664047 \\
\hline & & Muzumwa & SK, CS & 4112 & $\overline{\mathrm{DQ} 662972}$ & $\overline{-}$ \\
\hline & & Muzumwa & SK, CS & 4113 & DQ662973 & - \\
\hline & & Muzumwa & SK, CS & 4114 & DQ662974 & - \\
\hline & & Chituta Bay & TV & 4538 & DQ662975 & - \\
\hline & & Ulwile Island & EV & TB 073 & - & DQ663062 \\
\hline & & Ulwile Island & EV & TB 125 & DQ663015 & DQ663063 \\
\hline & & Ulwile Island & EV & TB 126 & $\overline{D Q 663016}$ & DQ663064 \\
\hline & & south of Mkangansi & EV & TB 872 & DQ663017 & DQ663067 \\
\hline \multirow[t]{6}{*}{ Synodontis petricola } & $\mathrm{EA}(\mathrm{LT})$ & Kapembwa & SK, CS & 3636 & DQ662976 & DQ663048 \\
\hline & & Chituta Bay & SK, CS & 3699 & DQ662977 & $\overline{\mathrm{DQ} 663050}$ \\
\hline & & Mpulungu & SK, CS & 3731 & DQ662978 & - \\
\hline & & Mpulungu & SK, CS & 3732 & DQ662979 & - \\
\hline & & Katoto & SK, CS & 3769 & DQ662980 & - \\
\hline & & Katoto & SK, CS & 3770 & DQ662981 & - \\
\hline \multirow[t]{6}{*}{ Synodontis polli } & $\mathrm{EA}(\mathrm{LT})$ & Kalambo Lodge & SK, CS & 3695 & $\overline{\mathrm{DQ} 662983}$ & DQ663049 \\
\hline & & Kasakalawe Lodge & SK, CS & 3710 & DQ662984 & - \\
\hline & & Kasakalawe Lodge & SK, CS & 3711 & DQ662985 & - \\
\hline & & Mpulungu & SK, CS & 3717 & DQ662986 & - \\
\hline & & Mpulungu & SK, CS & 3733 & DO662987 & DQ663052 \\
\hline & & ?*** & SK, CS & 4030 & $\overline{D Q 662988}$ & - \\
\hline
\end{tabular}


Table 2: List of specimens used for this study (Continued)

\begin{tabular}{|c|c|c|c|c|c|c|}
\hline & & Mtondwe Island & SK & 4539 & DQ662982 & - \\
\hline & & Ulwile Island & EV & TВ 072 & DQ663018 & DQ66306I \\
\hline \multirow[t]{5}{*}{ Synodontis sp. nov. } & $\mathrm{EA}(\mathrm{LT})$ & Mpulungu & SK, CS & 3718 & $\underline{D Q 662989}$ & DQ66305I \\
\hline & & Mpulungu & SK, CS & 3775 & $\overline{\mathrm{DQ} 662990}$ & $\overline{\mathrm{DQ} 663054}$ \\
\hline & & Gombe & SK, CS & 3776 & DQ662991 & - \\
\hline & & ?*** & SK, CS & 4031 & DQ662992 & DQ663055 \\
\hline & & Tanganyika Lodge & SK, CS & 4532 & $\mathrm{DQ} 662993$ & - \\
\hline \multirow[t]{2}{*}{ Synodontis nigromaculatus } & $\mathrm{EA}(\mathrm{LT}, \mathrm{R})$ & Lake Mweru & RS & 4342 & $\underline{D Q 662954}$ & DQ663043 \\
\hline & & Lake Mweru & RS & 4339 & DQ662955 & DQ663045 \\
\hline \multirow{2}{*}{ Synodontis zambezensis } & $E A(R)$ & Cinzombo Lodge; Luagwa R. & CK & 3977 & DO662952 & - \\
\hline & & Nsefu Lagoon; Luangwa R. & CK & 3978 & $\underline{D Q 662953}$ & DQ663039 \\
\hline \multirow[t]{2}{*}{ Synodontis angelicus } & CA (Congo R.) & ?*** & SK & 3744 & $\overline{\mathrm{DQ} 662944}$ & DQ663033 \\
\hline & & ?*** & SK & 3745 & $\mathrm{DQ} 662945$ & - \\
\hline Synodontis brichardi & CA (Congo R.) & ?*** & SK & 3993 & DQ662943 & DQ663035 \\
\hline \multirow[t]{3}{*}{ Synodontis eupterus } & WA, Nile & ?*** & SK & 3861 & $\underline{\mathrm{DQ} 662956}$ & DQ663036 \\
\hline & & ?*** & SK & 4088 & $\mathrm{DQ} 662957$ & - \\
\hline & & ?*** & SK & 4108 & DQ662958 & DQ663037 \\
\hline Synodontis flavitaeniatus & CA (Congo R.) & ?*** & JS & 75 & - & DQ663077 \\
\hline \multirow[t]{3}{*}{ Synodontis nigrita } & WA, Nile & ?*** & SK & 3868 & DQ662947 & DQ663038 \\
\hline & & ?*** & SK & 4337 & DQ662948 & DQ66304I \\
\hline & & ?*** & SK & 4338 & DQ662949 & DQ663042 \\
\hline \multirow[t]{3}{*}{ Synodontis nigriventris } & CA (Congo R.) & ?*** & SK & 3700 & DQ662941 & DQ663030 \\
\hline & & ?*** & SK & 3701 & DQ662942 & - \\
\hline & & ?*** & JS & 56 & $\mathrm{DQ} 663021$ & DQ663058 \\
\hline Synodontis ocellifer & WA & ?*** & SK & 3994 & DQ662960 & DQ663031 \\
\hline Synodontis polystigma & CA (Congo R.) & Lake Mweru & RS & 4341 & $\overline{\mathrm{DQ} 662951}$ & $\overline{\mathrm{DQ} 663044}$ \\
\hline \multirow[t]{3}{*}{ Synodontis robbianus } & WA (Niger R.) & ?*** & SK & 3702 & $\underline{D Q 662938}$ & DQ663029 \\
\hline & & ?*** & SK & 3703 & DQ662939 & - \\
\hline & & ?*** & SK & 4089 & DQ662940 & - \\
\hline Synodontis robertsi & CA (Congo R.) & ?*** & SK & 4336 & $\underline{D Q 662946}$ & DQ663040 \\
\hline Synodontis schoutedeni & CA (Congo R.) & ?*** & SK & 3860 & DQ662950 & DQ663034 \\
\hline Synodontis velifer & WA & ?*** & WK & 3995 & DQ662959 & DQ663032 \\
\hline Chiloglanis sp. & & Lunzua R. & SK, CS & 3865 & $\underline{D Q 662935}$ & DQ663026 \\
\hline \multirow[t]{2}{*}{ Microsynodontis batesii } & & $?^{* * * *}$ & SK & 4024 & $\overline{\mathrm{DQ} 662936}$ & DQ663027 \\
\hline & & ?*** & SK & 4025 & DQ662937 & DQ663028 \\
\hline
\end{tabular}

*CA, Central Africa; LK, Lake Kivu; LM, Lake Malawi; LT, Lake Tanganyika; LV, Lake Victoria; M, Malagarazi River; R, East African rivers; WA, West Africa;

**CS, Christian Sturmbauer; CK, Cyprian Katongo; EV, Erik Verheyen; JS, Jos Snoeks; RS, Robert Sinyinza; SK, Stephan Koblmüller; TV, Toby Veall; WK, Walter Köhldorfer; WS, Walter Salzburger

***samples obtained through ornamental fish trade. Coordinates of sampling localities (when available):

LT - Chituta Bay, S 08 $44^{\prime}$ E $31^{\circ} 09^{\prime} ;$ Gombe, S 08 $47^{\prime}$ E $31^{\circ} 0 I^{\prime} ;$ Kalambo Lodge, S $08^{\circ} 39^{\prime}$ E $31^{\circ} 13^{\prime} ;$ Kapembwa, S $08^{\circ} 37^{\prime}$ E $30^{\circ} 5 I^{\prime} ;$ Kasakalawe, S

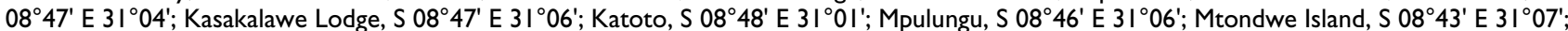
Muzumwa, S $08^{\circ} 42^{\prime} \mathrm{E} 31^{\circ} \mathrm{I} 2^{\prime}$; south of Kalambo, S $08^{\circ} 37^{\prime} \mathrm{E} 31^{\circ} \mathrm{I} 2^{\prime}$; south of Mkangansi, S $06^{\circ} 37^{\prime} \mathrm{E} 30^{\circ} 18^{\prime}$; Tanganyika Lodge, S $08^{\circ} 47^{\prime} \mathrm{E} 31^{\circ} 05^{\prime}$; Ulwile Island, $S 07^{\circ} 72^{\prime}$ E $30^{\circ} 34^{\prime}$ Lunzua R. (near Mwanangwa), S $08^{\circ} 57^{\prime} \mathrm{E} 31^{\circ} 10^{\prime}$

distances within the East African clade were $23.7 \%$ in the control region and 5.9\% in ND6 (in both cases involving the species pair $S$. njassae and S. multipunctatus). The two gene segments analyzed, thus, corroborate the observation that in the mitochondrial genome the non-coding control region generally evolves about two to five times faster than protein coding genes [28].

In our phylogenetic analyses, the internal branches interrelating major Central and West African lineages were short and, hence, the tree topologies remained somewhat unresolved and the branching topology varied depending on the tree-building algorithm used. This seems to suggest that several Central and West African lineages originated almost contemporaneously in the course of a major cladogenetic event. However, a much more thorough sampling and the analysis of a more slowly evolving gene segment (e.g., RAG1 [29]) would be necessary to shed light on this part of the evolutionary history of Synodontis in Africa. Our analyses consistently revealed that the Central and West African members of the genus Synodontis are ancestral to the East African representatives. The monophyly of the East African clade is clearly seen in the composite consensus tree (Fig. 3) based upon six most parsimonious trees [tree length, 49,875 steps; consistency index (CI) excluding uninformative characters, 0.47; retention index (RI), 0.74; rescaled consistency index (RC), 0.38], the neighbor joining (NJ) tree, the maximum 
A
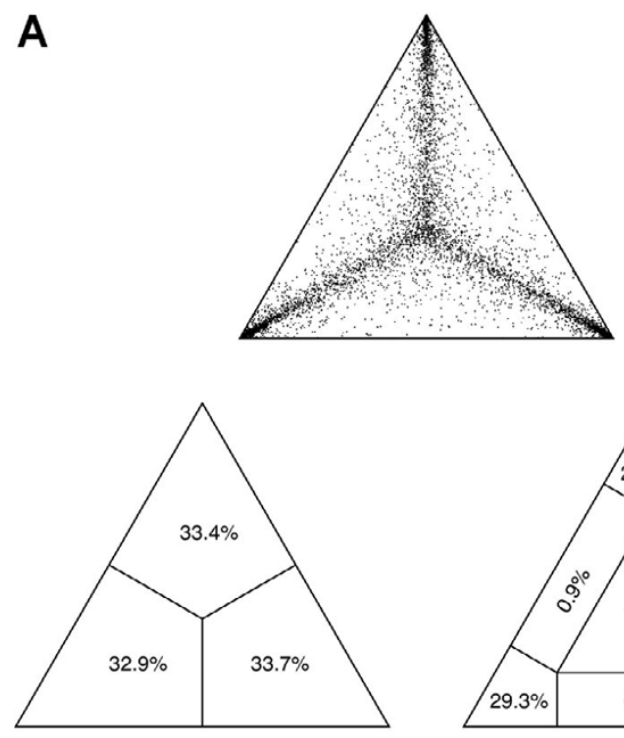

Figure 2

Results from the likelihood mapping analysis. (a) In theanalysis of the entire dataset, a percentage fraction of $89.4 \%$ of all quartets was fully resolved (and $7.8 \%$ were not resolved). (b) In the reduced dataset, $88.7 \%$ of the quartets were resolved $(7.9$ $\%$ were not resolved). This points to a strong phylogenetic signal in the data.
B
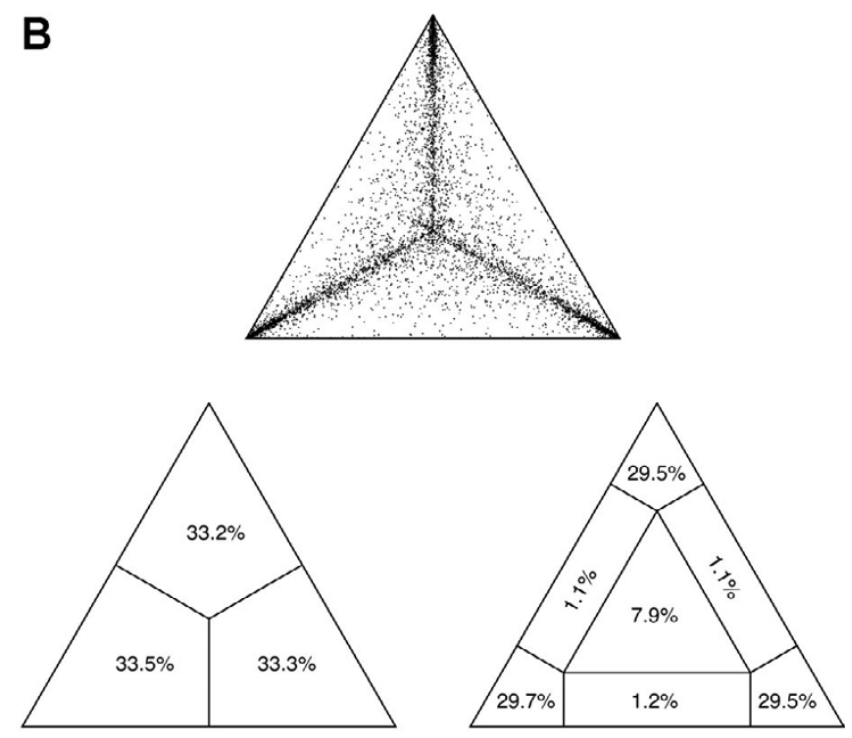

likelihood (ML; Fig. 4) tree and the Bayesian inference phylogeny. The monophyly of the East African representatives was further confirmed by the individual analysis of the mitochondrial gene segments, the control region and the ND6 gene (trees not shown).

The phylogenetic analyses of the East African Synodontis species revealed a similar outcome compared to that of the ancestral Central and West African lineages, with relatively short branches interrelating the main lineages (and low bootstrap support and posterior probabilities for these branches), indicating an almost contemporaneous origin of the main East African Synodontis lineages. Six distinct mitochondrial lineages can be distinguished within the East African clade of Synodontis. The species $S$. nigromaculatus, S. zambezensis, S. njassae and S. victoriae constitute separate clades, while the remaining Lake Tanganyika species can be divided into two distinct genetic lineages. The first Tanganyikan clade contains S. granulosus and the cuckoo catfish (S. multipunctatus); the second Tanganyikan clade includes $S$. dhonti, S. petricola, S. polli and $S$. sp. nov. In the maximum parsimony (MP) and NJ tree of the reduced dataset, the two clades of Lake Tanganyika Synodontis were resolved as a monophyletic group, albeit with low bootstrap support. In ML and BI, on the other hand, the two Tanganyikan clades were not resolved as sister groups, and S. victoriae was placed as sister group to the clade comprising $S$. dhonti, S. petricola, $S$. polli and S. sp. nov. - with similarly low support values. The fourcluster-likelihood-mapping (Fig. 5) favors a topology with a monophyletic origin of Lake Tanganyika Synodontis, and $S$. victoriae being more closely related to $S$. nigromaculatus, S. zambezensis and S. njassae. A Shimodaira-Hasegawa test [30] based on the tree topologies obtained from the reduced data set revealed that there are no significant differences between the topologies obtained by the different algorithms $(\mathrm{P}<0.05)$.

Within the second Tanganyikan clade the branching order among the four species S. dhonti, S. petricola, S. polli, S. sp. nov. differed with respect to the tree-building algorithm used. Together with the low bootstrap values and posterior probabilities this again points to an event of rapid cladogenesis [31]. In the other Tanganyikan clade, we observed relatively long branches (see Fig. 4), and also the uncorrected pairwise distances indicated a faster evolutionary rate in the cuckoo catfish (see above). For example, the maximum uncorrected pairwise distance in the control region in S. multipunctatus was $6.5 \%$, whereas in $S$. njassae a maximum uncorrected pairwise distance of only $1.5 \%$ was found. Relative rate tests with RRTree indeed recovered a significantly higher $(\mathrm{P}<0.01)$ substitution rate for $S$. multipunctatus compared to all other East African species. This was found for both gene segments.

In order to tentatively date the major cladogenetic events in Synodontis in East Africa, we used r8s [32] and applied different calibration points for our analyses. In our first round of analysis, in which we applied all available dates, we obtained an age of 12.24 million years (MY) for the 


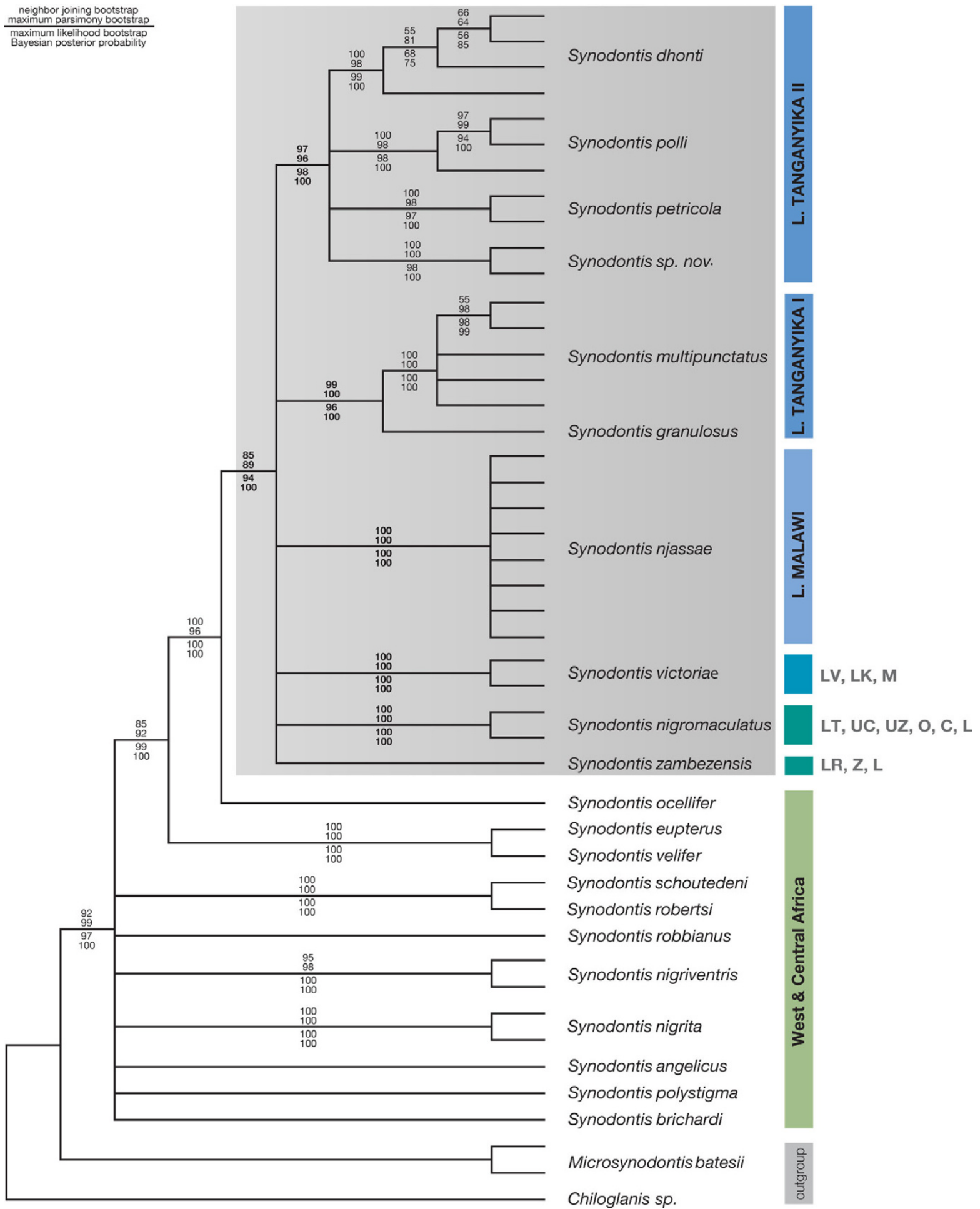

Figure 3

Composite consensus tree of the phylogenetic analyses. The strictconsensus of the neighbor-joining tree, the most parsimonious trees, the optimal maximum likelihood topology (see Fig.4) and the Bayesian inference tree is shown. Numbers above the branches are neighbor-joining and maximum parsimony bootstrap values, numbers below the branches represent maximum likelihood bootstraps and Bayesian posterior probabilities. The grey box indicates the East African clade of Synodontis. 
Table 3: Dating of the major cladogenetic events in Synodontis with r8s. We ran three independent analyses in r8s [32] with different calibration points using the maximum estimated age for the lacustrine habitat in lakes Malawi (I MY [49]) and Tanganyika (6 MY [4648]), as well as the minimum age of the East African clade of Synodontis as suggested by the oldest known Synodontis fossil in that region (>20 MY [45]). In the first analysis, all three calibrations were applied (1/6/20 calibration); in the second cycle, we used the Lake Malawi and the fossil calibration ( $1 / 20$ calibration); in the third round, we only used the fossil based calibration ( 20 calibration). The numbers indicate the average value (in MY) obtained from a bootstrap approach with 30 replicates, the minimum and maximum values are depicted in round brackets (in italics). Square brackets indicate the time constraints used for the different r8s analyses and the range of the actual numbers used in the bootstrap replicates (in round brackets). The estimates for the age of the entire genus Synodontis should be interpreted with caution, as the values lie outside our range of calibration points

\begin{tabular}{|c|c|c|c|}
\hline Clade & I/6/20 MY calibration & I/20 MY calibration & 20 MY calibration \\
\hline Synodontis & $34.54(23.42-38.14)$ & $35.39(24.0 I-38.53)$ & $37.26(22.87-40.12)$ \\
\hline East African clade & {$[>20(20-20.49)]$} & {$[>20(20-20.45)]$} & {$[>20(20-22.53)]$} \\
\hline L. Tanganyika I & $12.24(11.29-13.17)$ & $12.36(11.36-13.29)$ & $12.89(\mid I .24-14.8 I)$ \\
\hline L. Tanganyika II & {$[<6(4.77-6)]$} & $7.5(5.48-12.1 I)$ & $7.88(5.76-12.36)$ \\
\hline S. multipunctatus & $2.15(0.97-2.37)$ & $2.21(1.61-2.43)$ & $2.31(1.64-2.58)$ \\
\hline L. Malawi (S. njassae) & {$[<1(0.99-1)]$} & {$[<1(0.99-1)]$} & $1.75(1.34-2.18)$ \\
\hline
\end{tabular}

most recent common ancestor (MRCA) of $S$. granulosus and S. multipunctatus (minimum estimate: $11.29 \mathrm{MY}$; maximum estimate: $13.17 \mathrm{MY}$ ), and an age of 2.15 MY (min.: 0.97; max.: 2.37) for the MRCA of the cuckoo catfish (S. multipunctatus) (see Table 3). When applying two calibration points only, we obtained highly similar values plus an age of 7.5 MY for the second Tanganyikan clade (min.: 5.48; max.: 12.11). The MRCA estimates did not change substantially when only the fossil calibration was used (Table 3). The age for the entire genus was estimated with ca. 35 MY (min.: 22.87; max.: 40.12). This result should, however, be interpreted with caution since these dates lie outside the range of our calibration points, and since we might not have represented the entire diversity of Synodontis in Central, South and West Africa.

\section{Discussion Mitochondrial phylogeny of the East African Synodontis species}

Although the genus Synodontis is the most species-rich and widespread genus of the Mochokidae accounting for about a quarter of all African siluriform species, there is no molecular phylogeny available for this group. Earlier attempts based on a small number of sequences of the mitochondrial cytochrome $b$ gene revealed a sister-group relationship between an East African clade (represented by S. zambezensis, S. nigromaculatus, S. njassae, and S. petricola) and some South-African representatives [33]. However, no Central and/or West African taxa have been included in this analysis that would allow placing the investigated species into a larger phylogenetic and phylogeographic context.

We were interested in the phylogeny and phylogeography of the East African Synodontis species and, therefore, combined the mtDNA sequences of East African representatives with those of eleven Central and/or West African species. Our analyses of the combined dataset as well as the separate analyses of each mitochondrial locus, consistently revealed the monophyly of the East African clade and its derived position compared to the Central and/or West African taxa (Figs. 3, 4). While the phylogenetic relationships between most of the more ancestral Central and/or West African representatives could not be resolved, which is most likely due to the large genetic distances among these taxa, we could identify a sister-group relationship between a clade comprised by $S$. velifer and $S$. eupterus and S. ocellifer plus the East African clade (Figs. 3, 4).

Within the East African clade, we could clearly identify six distinct lineages: $S$. zambezensis; S. nigromaculatus; S. victoriae (Lake Victoria); S. njassae (Lake Malawi); S. granulosus and S. multipunctatus (Lake Tanganyika I); S. dhonti, S. polli, S. petricola, S. sp. nov. (Lake Tanganyika II). However, it was not possible to resolve the phylogenetic relationships between these lineages, as indicated by the short branches interconnecting them, the lacking statistical support for these branches, and the fact that different tree building algorithms led to different phylogenetic hypotheses with regard to the relative position of these lineages. Such a lack of phylogenetic signal in ancestral branches is frequently observed in cases of relatively rapid lineage splitting events $[12,22,29,31,34-36]$, e.g., as consequence of the synchronized fragmentation of a founder population into allopatric units [31]. We, thus, suggest a scenario for the evolution of Synodontis in East Africa, in which one ancestral (colonizing) species was split into at least six sub-lineages within a relatively short period of time, and that - at least in some cases - these sub-lineages diversified further, albeit in isolation from each other. In this context, it is interesting to note that hybrids can artificially be produced between two of the lineages, the riverine taxa S. zambezensis and S. nigromaculatus [33,37]. It is, however, unlikely that hybridization distorted our phylogenetic signal, as most of the lineages exclude each other 


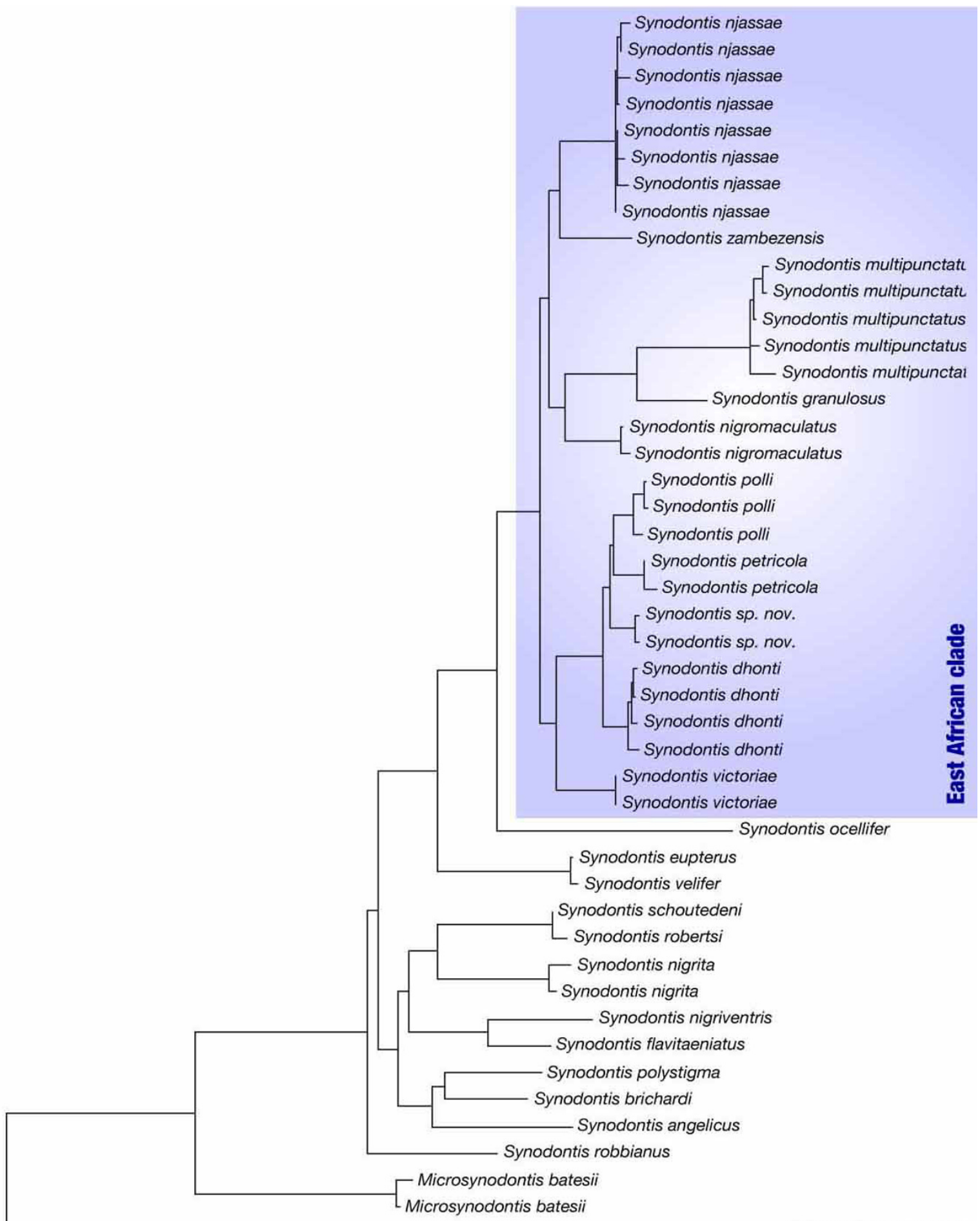

Chiloglanis sp. 'Lunzua'

0.05 substitutions/site

Figure 4

Maximum likelihood tree. Maximum likelihood topology based on the $\mathrm{K} 8 \mathrm{Iuf}+\mathrm{I}+\Gamma$ model of molecular evolution [70] with nucleotide frequencies $A, 0.358 \mathrm{I}, \mathrm{C}, 0.2676, \mathrm{G}, 0.1368, \mathrm{~T}, 0.2375$, proportion of invariable sites (I), $0.246 \mathrm{I}$, gamma shape parameter $(\alpha), 0.7306$, and $R$-matrix $A \leftrightarrow G, A \leftrightarrow T, C \leftrightarrow G$ and $G \leftrightarrow T, 1.0000 ; A \leftrightarrow G, 7.7875$ and $C \leftrightarrow T, 1.2463$. The blue box indicates the East African clade of Synodontis. 


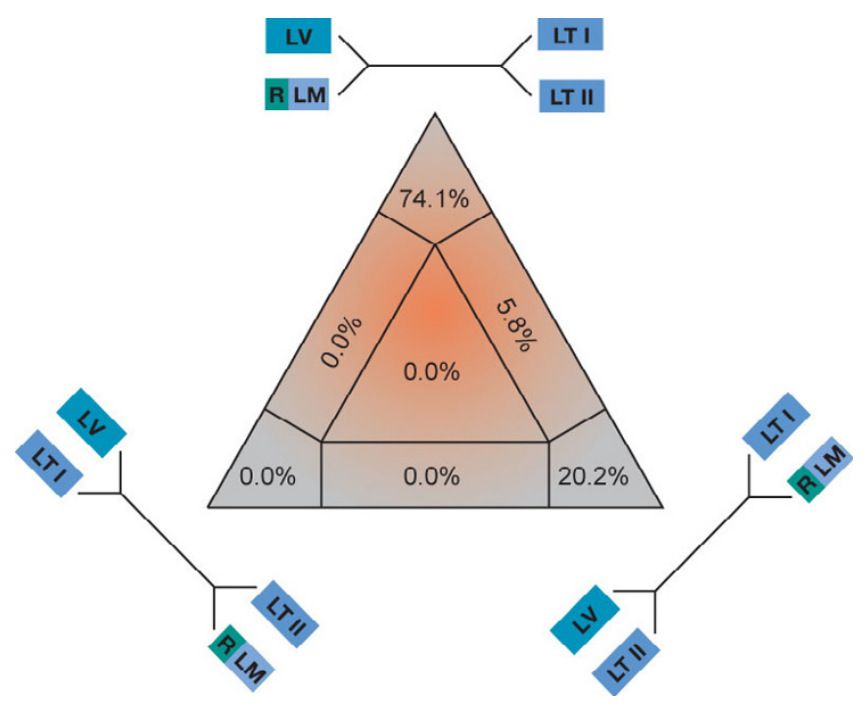

Figure 5

Four-cluster likelihood mapping analysis. The topology with a monophyly of the two endemic Tanganyikan clades receives the highest support. LM, Lake Malawi (S. njassae); LT I, first Lake Tanganyika clade; LT II, second Lake Tanganyika clade; LV, Lake Victoria (S. victoriae); R, riverine representatives.

geographically so that no natural hybridization was and is possible. The specimens of the only two species that partially overlap in range (S. zambezensis and S. nigromaculatus) showed reciprocal monophyly and appeared as distinct evolutionary units with an average sequence divergence of ca. $12 \%$ in the control region and ca. $4.5 \%$ in ND6.

Lake Tanganyika is the only East African lake that harbors a small assemblage of endemic Synodontis species [16,17]. Our phylogenetic analyses indicate the existence of two separate lineages of Synodontis in Lake Tanganyika (see Fig. 3) (note that also the non-endemic S. nigromaculatus is found in that lake). The first lineage comprises the relatively large Tanganyikan representative $S$. granulosus and the cuckoo catfish (S. multipunctatus), a brood parasite of mouth-brooding cichlids [25] (Fig. 1c). The second Tanganyikan clade includes the species $S$. dhonti, S. polli, $S$. petricola, and a yet undescribed species. There are some indications, e.g., the four-cluster likelihood mapping analysis (Fig. 5), for a monophyly of the two Lake Tanganyikan clades, although statistical support in the individual bootstrap analysis and in the Shimodaira-Hasegawa test is lacking. While in both Tanganyikan clades the monophyly of the taxa was supported with high bootstrap values and Bayesian posterior probabilities, the phylogenetic relationships between the four lineages of the second Tanganyikan clade could not be resolved with high confidence (Fig. 3). We interpret these short branches as the result of the relatively rapid lineage splitting at the beginning of the formation of Lake Tanganyika. It also seems possible that some hybridization took place in the early phases of species formation (see e.g., [38]), which could be tested with nuclear DNA sequences. However, it is unlikely that the observed lack of resolution in some branches interrelating main lineages (or taxa) is due to the markers used, since, overall, we observe a sufficiently strong phylogenetic signal in the dataset (Fig. 2), and since the control region is the fastest evolving section of the mitochondrial genome.

\section{Phylo-chronology of Synodontis in East Africa}

The reconstruction of divergence times from molecular data or phylogenies is not without potential pitfalls (see e.g., $[39,40])$. Yet, such time estimates are useful for providing an approximate framework that puts diversification events into a temporal framework. Our phylochronological reconstruction of the major cladogenetic events in the East African clade of Synodontis (Table 3) is based on three independent calibration points, which were used in different combinations. Because these calibration points are derived from estimates, it is important to note that our approximations should be interpreted cautiously. For example, we used a minimum age of 20 MY for the MRCA of the East African clade, based on the oldest known fossils in that area [41-45]. These Early Miocene fossils are, however, not particularly well dated (although $20 \mathrm{MY}$ seems like a good approximation [43]), they have not been assigned to extant species, and the possibility always remains that still older fossils exist. However, together with the internal calibration pointes - the ages of lake basins - the estimated scenario for the evolution and phylogeography of Synodontis in East Africa is congruent with geological and paleolimnological events.

With regard to the entire East African clade of Synodontis, the oldest known fossils from the Early Miocene are relatively close to the estimated age of the MRCA of that clade. In our bootstrap replicates, the age of the MRCA of the East African clade was estimated between 20 (the constrained minimum age in the analyses) and 22.53 MY. For the MRCA of the first Tanganyikan clade, with S. granulosus and S. multipunctatus, we obtained an age of 11.2414.81. This is older than the age of the onset of a truly lacustrine deepwater habitat in Lake Tanganyika [46-48], suggesting that the split between these two taxa took place before the ecosystem of a deep tropical lake has formed (e.g., in the riverine environment of the Congo and/or Proto-Malagarazi River) or, possibly more likely, a colonization in the initial period of lake formation when extensive swampy areas with shallow basins are likely to have existed in the area of present Lake Tanganyika. Thus, although both $S$. granulosus and, particularly, the cuckoo catfish (S. multipunctatus) are highly specialized lake spe- 
cies, their ancestors were riverine fish that seem to have independently achieved their lacustrine lifestyle. In contrast, the second Tanganyikan clade appears to have undergone its primary radiation at a later stage, most likely in a lacustrine (or semi-lacustrine) environment (ca. 5-8 MYA; although the maximum values from individual bootstrap replicates indicate that even older estimates are possible). The only independent estimation for the MRCA of S. njassae from Lake Malawi revealed an age of 1.34$2.18 \mathrm{MY}$. We find that the cuckoo catfish (S. multipunctatus) has diverged after about 2 MYA (0.97-2.58 MYA). Interestingly, this would be immediately after the host lineage of the cuckoo catfish, the mouthbrooding haplochromine cichlids, has initiated its radiation in Lake Tanganyika, according to a recent calibration [9].

Our strategy of carrying out the analysis in three cycles also aimed to test the validity of some calibration points, such as the age of the MRCA within Lake Malawi and the second clade in Lake Tanganyika. While our analyses revealed highly consistent results for the MRCA of the first Tanganyikan clade and that of S. multipunctatus (Table 3), the estimates for the MRCA of S. njassae (Lake Malawi) and that of the second Tanganyikan clade are slightly older than expected based on the presumed formation of the truly lacustrine habitat in both lakes [46-49]. This could, of course, be due to analytical limitations in estimating divergence times based on molecular phylogenies. Alternatively, it may indicate the actual coalescence age of the riverine MRCA of both lineages. However, it could also mean that the lake basins are somewhat older or that the divergence of Synodontis in the basins of lakes Malawi and Tanganyika began before the establishment of the present lacustrine habitat with its characteristic deepwater conditions, e.g., in more shallow pools in the transition phase between a swampy habitat of a proto-lake and a real lake.

\section{Phylogeography of Synodontis in East Africa}

Based on our phylogenetic and phylo-chronological analysis of Synodontis in East Africa, we can outline the following overall phylogeographic scenario: It seems that after an initial colonization of East Africa through a potentially widespread Central and/or West African representative (probably about 20 MYA), at least six lineages of Synodontis evolved that are each confined to particular geographic regions. The rapid spread of East African Synodontis can be explained by a colonization of the area via the ancient Congo-Malagarazi River connection, and incidents of drainage catchments towards the Nile systems (in the North) and between the Upper Congo and Zambezi drainage (in the South) (see ref. [50] and citations therein). For example, the two riverine species S. nigromaculatus and S. zambezensis are widely distributed in Southern and Eastern Africa (but are phylogenetically distinct from the South African clade [33]). The black-spotted squeaker catfish ( $S$. nigromaculatus) is found in the Cunene River, the Okavango River, the upper reaches of the Congo River, the upper Zambezi basin, the Limpopo as well as in Lake Tanganyika, demonstrating the existence of fish accessible water-ways through-out eastern and southern Africa until recently (see e.g., $[9,35])$. The plain squeaker (S. zambezensis) is found in the Zambezi and Limpopo system, as well as in Lake Rukwa. The maximum-likelihood analysis (Fig. 4) suggested a sister-group relationship between the easternmost species, S. zambezensis, and $S$. njassae from Lake Malawi, and between $S$. nigromaculatus and the first Tanganyikan clade. Both hypotheses would, phylogeographically, make sense. However, a more detailed sampling and, particularly, much longer sequences would be necessary to confirm this hypothesis.

With our sampling strategy and phylogenetic analyses we are able to present a robust hypothesis for the evolution of Synodontis in East Africa (see above). However, we are not able to address questions related to the phylogeography of single species as has been undertaken for the clariid Clarias gariepinus [51]. It would, for example, be interesting to compare the phylogeography of S. nigromaculatus to one branch of haplochromine cichlids that have a comparable distribution range $[9,35,50]$. Similarly, a detailed phylogeographic scenario for S. victoriae and S. zambezensis could be used to test the existence of past fish-accessible connections between large East African lakes (see e.g., $[9,10,18])$. A much more thorough sampling of selected species and phylogeographic hypotheses for single species would be necessary in order to resolve these open questions.

\section{Comparative phylogeography between East African cichlids and squeaker catfishes}

One of our goals for this study was to compare the phylogeny and phylogeography of the East African squeaker catfishes to the cichlid fishes, for which an impressive amount of data exists (see e.g., [9-12,35,52,53]). Our analyses reveal that, first of all, the initial diversification of Synodontis in East Africa is much older compared to the radiation of the extant cichlid species flocks in that area. (Note that there are representatives of more ancient cichlid lineages in East Africa; some of these have colonized East Africa secondarily $[12,21]$.) In fact, the main lineages of Synodontis are likely to have existed before the oldest lake, Lake Tanganyika, has formed. A Central to West African origin is, however, likely for both groups, and it seems plausible that the ancestors of both the East African cichlid radiations and the East African Synodontis clade colonized the area at about the same time - with the Congo River system playing a zoogeographic key-role for the spread of both groups. 
A main difference between the East African cichlids and Synodontis is also the evolutionary role that Lake Tanganyika has played. Lake Tanganyika is not only a reservoir for the most ancestral cichlid lineages in East Africa, but it has been identified as the cradle from which the most species-rich and widespread group of East African cichlids, the haplochromines, has evolved (see e.g., $[9,12,54]$ ). This "out of Tanganyika scenario" [9] implies that the species flocks of lakes Malawi and Victoria are derived from the older Tanganyikan radiation $[9,12,54]$. In Synodontis, we do not find evidence that a formerly endemic Tanganyikan lineage left the lake secondarily to colonize rivers and, subsequently, other lakes. Instead, Lakes Malawi and Victoria were seeded independently by ancestral lineages of Synodontis. Consequently, different and - in most cases - more ancient connections between water-systems were used by Synodontis to colonize East Africa.

There are, however, also similarities in the distribution of cichlids and squeaker catfishes. The range of the blackspotted squeaker catfish (S. nigromaculatus), for example, is similar to that of one lineage of haplochromine cichlids, the Congolese-South African clade (according to ref. [9]), and S. zambezensis overlaps with Pseudocrenilabrus $[9,50]$. A much more detailed sampling would be necessary to test for a putative congruence of time-scale and routes of colonization between these riverine cichlids and squeaker catfishes. Similarly, the occurrence of $S$. victoriae in lakes Kivu and Victoria seems to support the close relatedness of the fish faunas of both lakes [10]. A detailed phylogeographic scenario for $S$. victoriae would thus be of interest to further test for the commonality of geological and palaeolimnological events affecting several lineages of fishes.

\section{The evolution of brood parasitism in the cuckoo catfish (S. multipunctatus)}

The most fascinating behavioral adaptation in Synodontis is certainly the evolution of brood parasitism in S. multipunctatus from Lake Tanganyika [25] (Fig. 1c). In the course of our sampling we found larvae of S. multipunctatus in the mouth of Simochromis babaulti and S. diagramma females (with up to three catfishes per female).

Our analyses resulted in two interesting findings regarding the evolution of cuckoo behavior in S. multipunctatus. First, our phylo-chronological analyses consistently revealed an age of about $2 \mathrm{MY}$ for the MRCA of $S$. multipunctatus. This coincides with the MRCA of the mouthbrooding haplochromines of Lake Tanganyika [9], to which the current host-species of $S$. multipunctatus belong. It thus seems that brood parasitism evolved in S. multipunctatus at an early stage of the radiation of the Tropheini in Lake Tanganyika. Secondly, we find an accelerated rate of molecular evolution in both gene segments in the rep- resentatives of $S$. multipunctatus, as shown by longer branches in the phylogenies, larger genetic distances, and relative rate tests. A faster rate of DNA sequence evolution in brood parasites has been described in African finches, and it has been argued that this might be the consequence of a dynamic co-evolutionary history [55]. Iterative coevolutionary processes between hosts and parasites might account for the observed significantly faster evolutionary rate in S. multipunctatus. Alternatively, there might be selective pressure to equalize the evolutionary rate in hostparasite systems. This could possibly explain why the mutation rate in the non-coding control region in S. multipunctatus approaches that observed in haplochromine cichlids [56] (6.5\%; MRCA: 2 MYA), while the remaining representatives of the East African clade of Synodontis show considerably lower evolutionary rates (e.g., S. njassae: $1.5 \%$; MRCA: 1-1.5 MYA).

\section{Conclusion}

Our phylogenetic and phylogeographic analyses of East African Synodontis species suggest the existence of at least six main lineages of Synodontis in East Africa that began to diversify about 20 MYA from a Central and/or West African ancestor. The six lineages show a clear-cut geographic pattern, and only the distributions of two riverine species, S. nigromaculatus and S. zambezensis, overlap. Representatives of three lineages are found in the oldest lake in the area, Lake Tanganyika, and two of these lineages are endemic and have undergone further diversification within the lake. The initial diversification of Synodontis in East Africa appears to be much older than that of the cichlid species flocks, yet, some taxa show similar geographic patterns compared to haplochromine cichlids, with which they often share the same habitat (in rivers and lakes). The endemic brood-parasitic cuckoo catfish (S. multipunctatus) from Lake Tanganyika seems to have diversified in parallel with its host species of the mouthbrooding modern haplochromines (the Tropheini). The significantly faster evolutionary rate in $S$. multipunctatus might be a consequence of co-evolutionary dynamics. Although Synodontis has colonized East Africa before the formation of the Great Lakes, which are home to the exceptionally diverse cichlid species flocks, and although the squeaker catfishes inhabit the same habitats as many of the cichlids, only a few species have evolved in one of the lakes. This, once more, illustrates the unparalleled, and still enigmatic, propensity of cichlid fishes to undergo explosive speciation.

\section{Methods}

\section{Specimen information and DNA methods}

This study is based upon a total of 91 individuals of 21 described and one so far undescribed species of Synodontis, mainly from Lakes Tanganyika, Malawi and Victoria, and several African river systems. As outgroup taxa we used one individual of Chiloglanis sp. and two individuals 
of Microsynodontis batesii $[57,58]$. Most of the specimens were sampled during several field expeditions from 1992 to 2004, while some additional samples were obtained from the aquarium trade (Table 2). Voucher specimens are available from the authors. Of all specimens, fin clips were taken and preserved in $96 \%$ ethanol.

We analyzed a 407 bp segment of the most variable part of the mitochondrial control region (D-loop) of 94 specimens (including the outgroup taxa) and $426 \mathrm{bp}$ of the more slowly evolving NADH dehydrogenase subunit 6 gene (ND6) of 52 specimens (including the outgroup taxa). We chose the mitochondrial control region to be able to directly compare our present results to the East African cichlid species flocks, for which the control region is the most common mitochondrial DNA marker $[9,10,12,35,50,59,60]$. The ND6 gene was chosen because it has previously been used in clariid catfishes [51]. We decided not to use the mitochondrial cytochrome $b$ gene, because previous analyses indicated a reduced phylogenetic signal in that gene with respect to the East African Synodontis species [33].

For DNA extraction we applied a proteinase $K$ digestion followed by protein precipitation with ammonium acetate. As primers for amplification and sequencing of the most variable part of the mitochondrial control region we used L-Pro-F [61] and TDK-D [62]. For ND6 we used the primers ND5G and ND6L [63]. The PCR reactions were prepared for a total volume of $17 \mu \mathrm{l}$ containing $0.085 \mu \mathrm{l}$ of Taq DNA polymerase (BioTherm ${ }^{\mathrm{TM}}$ ), $1.7 \mu \mathrm{l}$ of each primer $(10 \mu \mathrm{M}), 1.7 \mu \mathrm{l}$ 10x dNTP mix, $1.7 \mu \mathrm{l} 10 \mathrm{x}$ buffer, $7.62 \mu \mathrm{l}$ high performance liquid chromatography (HPLC) water, and $2.5 \mu \mathrm{l}$ of the extracted DNA. Amplification was performed on a GeneAmp 9700 PCR system (Applied Biosystems) under the following conditions: an initial denaturation phase at $94^{\circ} \mathrm{C}$ for 3 min followed 45 cycles with denaturation at $94^{\circ}$ for $30 \mathrm{sec}$, primer annealing at $50^{\circ} \mathrm{C}$ for $30 \mathrm{sec}$, and extension at $72^{\circ} \mathrm{C}$ for $1 \mathrm{~min} 30 \mathrm{sec}$, with a final extension phase at $72^{\circ} \mathrm{C}$ for $10 \mathrm{~min}$. The PCR-products were purified with ExoSAP-IT (Exonuclease I and Shrimp Alkaline Phosphatase in buffer; Amersham Biosciences) prior to being added as template for chain termination sequencing following the protocol described in ref. [64]. DNA fragments were purified with Sephadex ${ }^{\mathrm{TM}} \mathrm{G}-50$ (Amersham Biosciences) following the manufacturer's instruction and subsequently visualized on an ABI 3100 capillary sequencer (Applied Biosystems). All sequences are available from GenBank under the accession numbers listed in Table 2.

\section{Phylogenetic analysis}

Alignment of the DNA sequences was performed using Clustal X [65] and improved by eye for the control region. Since all species were resolved as respectively mono- phyletic clades in a preliminary NJ tree (tree not shown) using all available sequences of the mitochondrial control region (calculated in PAUP* 4.0b10; [66]), we chose 52 taxa (including outgroup taxa) for amplification of the ND6 fragment. Several individuals had long insertions (> $100 \mathrm{bp}$ ) in the control region that were excluded for phylogenetic analyses. The combined dataset of control region and ND6, including 46 taxa, was used to reconstruct the phylogenetic relationships among the investigated Synodontis species. We applied neighbor-joining (NJ), maximum parsimony (MP) and maximum likelihood (ML) analyses in parallel, using the computer program PAUP*. Phylogenetic relationships were also reconstructed by Bayesian inference (BI) using MrBayes 3.1 [67].

To assess the degree of saturation of transition (ti) and transversion (tv) mutations at each codon position of the ND6 gene, we plotted the number of mutations against the percentage of sequence divergence of all pairwise comparisons (not shown). Based on the estimated ti/tv ratio inferred from these pairwise comparisons we derived a proper weighting scheme for a weighted MP analysis. Due to the estimated ti/tv ratio of 6.81 for third codon positions of two-and threefold degenerate amino acids, 2.63 for third codon positions of fourfold degenerate amino acids, 2.00 for second codon positions, and 1.75 for first codon positions we applied the following weighting scheme (tv/ti): 70:10 for third codon positions of twoand threefold degenerate amino acids, 26:10 for third codon positions of fourfold degenerate amino acids, 70:35 for second codon positions, and 70:28 at first codon positions. C/T substitutions at the first codon position of leucine were treated as a fifth base and were downweighted to the same weight as transitions at the third codon positions. To achieve a proper weighting scheme for the control region, we first performed a sliding window analysis to define regions exhibiting different degrees of variation $(<10 \%$, low variable; $10-20 \%$, high variable; $>20 \%$, hyper variable) [68]. Despite considerable saturation, transition mutations contain substantial information necessary to resolve the relationships of evolutionary young splits, without obscuring the deep splits when they are down-weighted according to their frequency in relation to transversion mutations [22]. We thus evaluated the degree of saturation of ti and tv for each partition of the control region separately, and based upon the estimated ti/tv ratios of 1.40, 2.43 and 2.28 for the low, high and hyper variable regions we obtained following weighting schemes (tv/ti): low variable, 70:56; high and hyper variable, 70:28. To evaluate an appropriate substitution model for the ML analysis, we calculated hierarchical likelihood ratio test statistics using the program Modeltest 3.06 [69]. The model recovered was K81uf $+\mathrm{I}+\Gamma[70]$ with nucleotide frequencies A, 0.3581, C, 0.2676, G, 0.1368, T, 
0.2375, proportion of invariable sites (I), 0.2461, gamma shape parameter $(\alpha), 0.7306$, and R-matrix $\mathrm{A} \leftrightarrow \mathrm{C}=\mathrm{G} \leftrightarrow \mathrm{T}+1 ; \quad \mathrm{A} \leftrightarrow \mathrm{T}+\mathrm{C} \leftrightarrow \mathrm{G}=1.2463 ; \quad$ and $\mathrm{A} \leftrightarrow \mathrm{G}=\mathrm{C} \leftrightarrow \mathrm{T}=7.7875$. For obtaining MP and ML topologies we applied heuristic search procedures with random addition of taxa and TBR branch swapping (1,000 replicates for MP; 100 replicates for ML). As standard measures of confidence we applied bootstrapping (1,000 pseudoreplicates for NJ and MP, 100 for ML). For the reconstruction of phylogenetic relationships by Bayesian inference analyses our data were partitioned by gene and codon position (only in ND6). Rate heterogeneity was set according to a gamma distribution with six rate categories (GTR model) for each data partition. Posterior probabilities were obtained from a 2,000,000-generation Metropolis-coupled Markov chain Monte Carlo simulation (four chains; chain temperature, 0.2; trees sampled every 100 generations), with parameters estimated from each data partition. A 50\% majority-rule consensus tree was constructed after a burn-in of $1 \%$, which is when likelihood values reached stationarity.

To obtain a potentially better insight into the phylogenetic relationships among the East African member of the genus Synodontis we repeated the NJ, MP, ML and BI analyses with a reduced dataset including the species $S$. dhonti, S. granulosus, S. multipunctatus, S. nigromaculatus, S. njassae, S. petricola, S. polli, S. sp. nov., S. victoriae and S. zambezensis, using S. eupterus, S. velifer and S. ocellatus as outgroup taxa, based on the first round of phylogenetic analyses. Proper weighting schemes for MP analysis were derived from estimated ti/tv-ratios as described above. Since no tv were observed for third codon positions of two-and threefold degenerate amino acids, we applied the same weighting scheme as in the overall data set for these codon positions. Based on the estimated ti/tv ratio of 2.49 for third codon positions of fourfold degenerate amino acids, 2.28 for second codon positions, and 1.19 for first codon positions we applied following weighting scheme (tv/ti): 25:10 for third codon positions of fourfold degenerate amino acids, 70:31 for second codon positions, and 70:59 at first codon positions. C/T substitutions at the first codon position of leucine were again treated as a fifth base and down-weighted to the same weight as transitions at the third codon positions. For the control region we obtained ti/tv ratios of 2.28, 3.20 and 2.18 for low, high and hyper variable regions resulting in a weighting ( $\mathrm{tv} / \mathrm{ti})$ of 70:31, 70:22 and 70:32, respectively. For NJ, ML and BI, the best fit substitution model, recovered by the hierarchical likelihood ratio tests implemented in Modeltest 3.06 [69], was $\mathrm{HKY}+\mathrm{I}+\Gamma[71]$ with base frequencies $\mathrm{A}, 0.3565$; C, 0.2814; G, 0.1308; T, 0.2313; ti/tv, 4.7844; I, 0.3046; and $\alpha, 0.5463$. A four-cluster likelihood mapping analysis [72] using the program TREE-PUZZLE 5.1 [73] was applied to test the hypothesis of the monophyly of the two endemic Tanganyikan clades.

To determine differences in substitution rates between East African representatives of the genus Synodontis and to test whether the cuckoo catfish ( $S$. multipunctatus) indeed shows an accelerated rate of molecular evolution as indicated by its long branch, we conducted a relative rate test as implemented in RRTree [74]. We therefore tested $S$. multipunctatus against the remaining East African taxa, applying the K2P substitution model [75].

We used r8s [32] to tentatively date the major cladogenetic events in Synodontis in East Africa. We used the maximum likelihood trees and applied the local molecular clock method with an optimization via the truncated newton method [76]. The analyses were performed in three cycles with different calibration points, and 30 bootstrap replicates for each cycle (the files for this bootstrapping approach were generated with Mesquite [77]; the maximum likelihood trees were generated with PAUP* [66] as described above). In the first cycle, we used all three available calibration points: $(i)$ the maximum age of about one million years for the lacustrine radiation of the Lake Malawi species $S$. njassae, based on the age of the truly lacustrine habitat [49] (see also refs. [9,56]); (ii) the maximum age of about six million years for the lacustrine radiation of the second Tanganyikan clade including $S$. dhonti, S. petricola, S. polli and S. sp. nov., based on the age of the truly lacustrine habitat in Lake Tanganyika [46-48] (see also refs. $[9,22,64]$ ) (Note that we did not use the first Tanganyikan clade because of the apparently deviating evolutionary rate in that clade and the possibility that $S$. granulosus might represent a separate lineage that existed before the formation of the lacustrine habitat in the Lake Tanganyika basin); and (iii) the minimum age of about 20 million years for the most recent common ancestor (MRCA) of the East African clade of Synodontis, based on the oldest Synodontis fossils in that area [41-45]. We note that these East African Synodontis fossils from the Early Miocene have not been assigned to extant species (see e.g., ref. [45]), which is difficult due to the diversity of the family and the fact that the criteria used for the identification of extant species are not applicable to the fossil specimens [78]. However, because these Synodontis fossils resemble extant East African species, and because of the rich fossil record since the Miocene, it is highly likely that these specimens belong to the East African clade. The second and third cycle of analyses aimed to corroborate internal calibrations. We, therefore, ran an analysis with a single calibration point at 20 million years for the minimum age of the East African clade, and an analysis, in which we constrained the maximum age for $S$. njassae to one million year and the minimum age for the East African clade to 20 million years. 


\section{Abbreviations}

BI, Bayesian inference; ML, maximum likelihood; MP, maximum parsimony; MRCA, most recent common ancestor; mtDNA, mitochondrial DNA; MY, million years; MYA, million years ago; ND6, NADH Dehydrogenase Subunit 6; NJ, neighbor joining; ti, transition mutation; $\mathrm{tv}$, transversion mutation.

\section{Authors' contributions}

SK, CS, EV, AM and WS designed the study and were involved in sampling. SK and WS carried out the molecular work and the analyses. All authors contributed to the preparation of the manuscript. They read and approved the final version.

\section{Acknowledgements}

We thank C. Kapasa, P. Ngalande, H. Phiri, L. Makasa, R. Shapola, D. Sinyinza, and the team at the Mpulungu Station of the Ministry of Agriculture and Cooperatives, Republic of Zambia as well as L. Mumba, G. Mutenda, and C. Katongo, from the University of Zambia in Lusaka for their cooperation during fieldwork. We are also grateful to C. Danady, C. Katongo, W. Köhldorfer, R. Sinyinza, J. Snoeks, and T. Veall for providing samples, to E. Hespeler and J. Hauck for technical assistance in the laboratory of AM, and to K. Sefc for valuable comments on the manuscript. This study was financed by the Austrian Science Foundation (grant PI7968) to CS, the Deutsche Forschungsgemeinschaft (DFG) to AM and WS. SK was further supported by the University of Graz and the Austrian Academy of Sciences (DOC-fellowship).

\section{References}

I. Fryer G, lles TD: The cichlid fishes of the Great Lakes of Africa: Their biology and Evolution. Edinburgh: Oliver \& Boyd; 1972.

2. Coulter GW, ed: Lake Tanganyika and its Life. London: Oxford University Press; 1991.

3. Greenwood PH: Morphology, endemism and speciation in African cichlid fishes. Verhandlungen der Deutschen Zoologischen Gesellschaft 1973, 66:115-124.

4. Boulenger G: Catalogue of the fresh-water fishes of Africa in the Brithish Museum (Natural History). London: British Museum for Natural History; 1898.

5. Stiassny MLJ, Meyer A: Cichlids of the Rift Lakes. Scientific American 1999, 280:64-69.

6. Kocher TD: Adaptive evolution and explosive speciation: the cichlid fish model. Nature Rev Genet 2004, 5:288-298.

7. Snoeks J, Rüber L, Verheyen E: The Tanganyika problem: comments on the taxonomy and distribution patterns of its cichlid fauna. In Speciation in Ancient Lakes Edited by: Martens K, Goddeeris G, Coulter GW. Stuttgart: Schweizerbart'sche Verlagsdruckerei; 1994:355-372.

8. Turner GF, Seehausen O, Knight ME, Allender CJ, Robinson RL: How many species of cichlid fishes are there in African lakes? Mol Ecol 200I, I 0:793-806.

9. Salzburger W, Mack T, Verheyen E, Meyer A: Out of Tanganyika: Genesis, explosive speciation, key-innovations and phylogeography of the haplochromine cichlid fishes. BMC Evolutionary Biology 2005, 5: 17.

10. Verheyen E, Salzburger W, Snoeks J, Meyer A: Origin of the superflock of cichlid fishes from Lake Victoria, East Africa. Science 2003, 300:325-9.

II. Meyer A, Kocher TD, Basasibwaki P, Wilson AC: Monophyletic origin of Lake Victoria cichlid fishes suggested by mitochondrial DNA sequences. Nature 1990, 347:550-3.

12. Salzburger W, Meyer A, Baric S, Verheyen E, Sturmbauer C: Phylogeny of the Lake Tanganyika cichlid species flock and its relationship to the Central and East African haplochromine cichlid fish faunas. Syst Biol 2002, 5 I : I I3-35.
13. Salzburger W, Meyer A: The species flocks of East African cichlid fishes: recent advances in molecular phylogenetics and population genetics. Naturwissenschaften 2004, 91:277-90.

14. Kornfield I, Smith PF: African Cichlid Fishes: Model systems for evolutionary biology. Annu Rev Ecol Syst 2000, 3 I : I63-196.

I5. Poll M: Revision de la faune ichthyologique du Lac Tanganika. Annales du Musée r. du Congo belge, Bruxelles, Zoologie, Series I 1946, 4:| $4 \mid-364$.

16. Coulter GW: Composition of the flora and fauna. In Lake Tanganyika and its life Edited by: Coulter GW. New York: Oxford University Press; 1991:200-274.

17. Brichard P: Cichlids and all other fishes of Lake Tanganyika. Neptune City, NJ: T H F Publications; 1989.

18. Coulter GW: Zoogeography, affinities and evolution, with special regard to the fish. In Lake Tanganyika and its Life Edited by: Coulter GW. New York: Oxford University Press; 1991:275-305.

19. Zardoya R, Vollmer DM, Craddock C, Streelman JT, Karl S, Meyer A: Evolutionary conservation of microsatellite flanking regions and their use in resolving the phylogeny of cichlid fishes (Pisces: Perciformes). Proc R Soc Lond B Biol Sci 1996, 263: I589-98.

20. Mayer WE, Tichy H, Klein J: Phylogeny of African cichlid fishes as revealed by molecular markers. Heredity I998, 80:702-7|4.

21. Klett V, Meyer A: What, if anything, is a Tilapia? Mitochondrial ND2 phylogeny of tilapiines and the evolution of parental care systems in the African cichlid fishes. Mol Biol Evol 2002, 19:865-83.

22. Koblmuller S, Duftner N, Katongo C, Phiri H, Sturmbauer C: Ancient divergence in bathypelagic Lake Tanganyika deepwater cichlids: mitochondrial phylogeny of the tribe Bathybatini. J Mol Evol 2005, 60:297-3I4.

23. Agnese JF, Teugels GG: Insight into the phylogeny of African Clariidae (Teleostei, Siluriformes): implications for their body shape evolution, biogeography, and taxonomy. Mol Phylogenet Evol 2005, 36:546-53.

24. Poll M: Révision des Synodontis africains (famille Mochokidae). Mus R Afr Centr Tervuren (Belg) Zool 1971, I 9 I: I-497.

25. Sato T: A brood parasitic catfish of mouthbrooding cichlid fishes in Lake Tanganyika. Nature 1986, 323:58-59.

26. Winemiller KO, Kelso LC-Winemiller: Comparative ecology of catfishes of the Upper Zambezi River floodplain. J Fish Biol 1996, 49:1043-1061.

27. Sanyanga RA: Food composition and selectivity of Synodontis zambezensis(Pisces: Mochokidae) in Lake Kariba, and the ecological implications. Hydrobiologia 1998, 36 I:89-99.

28. Meyer A: Evolution of mitochondrial DNA in fishes. In Biochemistry and molecular biology of fishes Volume 2. Edited by: Hochachka PW, Mommsen TP. Amsterdam: Elsevier Science Publishers; 1993: I-33.

29. Clabaut C, Salzburger W, Meyer A: Comparative phylogenetic analyses of the adaptive radiation of Lake Tanganyika cichlid fish: nuclear sequences are less homoplasious but also less informative than mitochondrial DNA. J Mol Evol 2005, 6 I:666-8I.

30. Shimodaira $\mathrm{H}$, Hasegawa $\mathrm{M}$ : Multiple comparisons of log-likelihoods with applications to phylogenetic inference. Mol Biol Evol 1999, 16: I I 14-I II6.

31. Sturmbauer C, Hainz U, Baric S, Verheyen E, Salzburger W: Evolution of the tribe Tropheini from Lake Tanganyika: synchronized explosive speciation producing multiple evolutionary parallelism. Hydrobiologia 2003, 500:5I-64.

32. Sanderson MJ: r8s: inferring absolute rates of molecular evolution and divergence times in the absence of a molecular clock. Bioinformatics 2003, 19:30I-2.

33. Bruwer EE, van der Bank FH, Steyn GJ, Wink M: Phylogenetic relationships between Synodontisspecies: some preliminary results. Afr J of Aquat Sci 2000, 25:89-92.

34. Sturmbauer C, Koblmuller S, Sefc KM, Duftner N: Phylogeographic history of the genus Tropheus, a lineage of rock-dwelling cichlid fishes endemic to Lake Tanganyika. Hydrobiologia 2005, 542:335-366.

35. Joyce DA, Lunt DH, Bills R, Turner GF, Katongo C, Duftner N, Sturmbauer C, Seehausen O: An extant cichlid fish radiation emerged in an extinct Pleistocene lake. Nature 2005, 435:90-5.

36. Baric S, Salzburger W, Sturmbauer C: Phylogeography and Evolution of the Tanganyikan Cichlid Genus Tropheus Based upon Mitochondrial DNA Sequences. J Mol Evol 2003, 56:54-68. 
37. Bruwer EE, van der Bank FH: Biochemical genetic markers (hybrizymes) to identify Synodontis zambezensis $x S$. nigromaculatushybrids (Teleostei: Mochokidae). Biochem Syst Ecol 2002, 30:641-649.

38. Seehausen O: Hybridization and adaptive radiation. Trends in Ecology and Evolution 2004, 19:198-207.

39. Page RDM, Holmes EC: Molecular evolution: a phylogenetic approach. Oxford: Blackwell Sciences; 1998.

40. Gillespie JH: The causes of Molecular Evolution. Oxford: Oxford University Press; 1991.

41. Greenwood PH: Fish remains from Miocene deposits of Rusinga Island and Kavirondo Province, Kenya. Annals and Magazine of Natural History 195I, I 2: I 192-I20 I.

42. Greenwood PH: Review of cenozoic freshwater fish faunas in Africa. Annals of The Geological Survey of Egypt 1974, 4:221-232.

43. Van Couvering JAH: Early records of freshwater fishes in Africa. Copeia 1977, 1977:163-166.

44. Van Neer W: New Late Tertiary fish fossils from the Sinda region, Eastern Zaire. African Study Monographs 1992:27-47.

45. Stewart KM: The freshwater fish of Neogene Africa (MiocenePleistocene): systematics and biogeography. Fish and Fisheries 200I, 2: 177-230.

46. Tiercelin J], Mondeguer A: The geology of the Tanganyika Trough. In Lake Tanganyika and its Life Edited by: Coulter GW. New York: Oxford University Press; 1991:7-48.

47. Lezzar KE, Tiercelin J], De Batist M, Cohen AS, Bandora T, Van Regensbergen P, Le Turdu C, Mifundu W, Klerkx J: New seismic stratigraphy and Late Tertiary history of the North Tanganyika Basin, East African Rift system, deduced from multichannel and high-resolution reflection seismic data and piston core evidence. Basin Research 1996, 8: I-28.

48. Cohen AS, Lezzar KE, Tiercelin JJ, Soreghan M: New paleogeographic and lake-level reconstructions of Lake Tanganyika: implications for tectonic, climatic and biological evolution in a rift lake. Basin Research 1997, 7:107-132.

49. Delvaux D: Age of Lake Malawi (Nyasa) and water level fluctuations. Mus R Afr Centr Tervuren (Belg) Dept Geol Min Rapp Ann 1995, 1995-1996:99-108.

50. Katongo C, Koblmüller S, Duftner N, Makasa L, Sturmbauer C: Phylogeography and speciation in the Pseudocrenilabrus philanderspecies complex in Zambian Rivers. Hydrobiologia 2005, 542:221-233.

5I. Giddelo CS, Arndt AD, Volckaert FAM: Impact of rifting and hydrography on the genetic structure of Clarias gariepinus in eastern Africa. J Fish Biol 2002, 60:1252-1266.

52. Kocher TD, Conroy JA, McKaye KR, Stauffer JR: Similar morphologies of cichlid fish in lakes Tanganyika and Malawi are due to convergence. Mol Phylogenet Evol 1993, 2:158-165.

53. Kocher TD, Conroy JA, McKaye KR, Stauffer JR, Lockwood SF: Evolution of NADH dehydrogenase subunit 2 in east African cichlid fish. Mol Phylogenet Evol 1995, 4:420-32.

54. Nishida M: Lake Tanganyika as an evolutionary reservoir of old lineages of East African cichlid fishes: Inferences from allozyme data. Experentia 1991, 47:974-979.

55. Sorenson MD, Payne RB: A single ancient origin of brood parasitism in African finches: implications for host-parasite coevolution. Evolution Int J Org Evolution 200I, 55:2550-67.

56. Sturmbauer C, Baric S, Salzburger W, Rüber L, Verheyen E: Lake level fluctuations synchronize genetic divergences of cichlid fishes in African lakes. Mol Biol Evol 200I, I 8: I44-54.

57. De Pinna MCC: Higher-level phylogeny of Siluriformes, with a new classification of the order (Teleostei, Ostariophysi). In PhD Thesis New York: The City University of New York; 1993.

58. M Hardman: The phylogenetic relationships among non-diplomystid catfishes as inferred from mitochondrial cytochrome b sequences; the search for the ictalurid sister taxon (Otophysi: Siluriformes). Mol Phylogenet Evol 2005, 37:700-20.

59. C Sturmbauer, A Meyer: Mitochondrial phylogeny of the endemic mouthbrooding lineages of cichlid fishes of Lake Tanganyika, East Africa. Mol Biol Evol 1993, 10:75I-768.

60. Sturmbauer C, Verheyen E, Meyer A: Mitochondrial phylogeny of the Lamprologini, the major substrate spawning lineage of cichlid fishes from Lake Tanganyika in Eastern Africa. Mol Biol Evol 1994, I I:691-703.
61. Meyer A, Morrissey JM, Schartl M: Recurrent origin of a sexually selected trait in Xiphophorus fishes inferred from a molecular phylogeny. Nature 1994, 368:539-42.

62. Lee WJ, Conroy J, Howell WH, Kocher TD: Structure and evolution of teleost mitochondrial control regions. J Mol Evol 1995, 4I:54-66.

63. Park LK, Brainard MA, Dightman DA, Winans GA: Low levels of intraspecific variation in the mitochondrial DNA of chum salmon (Oncorhynchus keta). Mol Mar Biol Biotechnol 1993, 2:362-70.

64. Duftner N, Koblmuller S, Sturmbauer C: Evolutionary relationships of the Limnochromini, a tribe of benthic deepwater cichlid fish endemic to Lake Tanganyika, East Africa. J Mol Evol 2005, 60:277-89.

65. Thompson JD, Gibson TJ, Plewniak F, Jeanmougin F, Higgins DG: The CLUSTAL_X windows interface: flexible strategies for multiple sequence alignment aided by quality analysis tools. Nucleic Acids Res 1997, 25:4876-82.

66. Swofford DL: PAUP* - Phylogenetic Analyses Using Parsinomy and other methods, version 4.0. In Book PAUP* - Phylogenetic Analyses Using Parsinomy and other methods, version 4.0, 4.0 ed City: Sinauer; 2003.

67. Huelsenbeck JP, Ronquist F: MRBAYES: Bayesian inference of phylogeny. Bioinformatics 200I, 17:754-755.

68. Sturmbauer C, Meyer A: Genetic divergence, speciation and morphological stasis in a lineage of African cichlid fishes. Nature 1992, 358:578-81

69. Posada D, Crandall KA: MODELTEST: testing the model of DNA substitution. Bioinformatics 1998, 14:817-8.

70. Kimura $M$ : Estimation of evolutionary distances between homologous nucleotide sequences. Proc Natl Acad Sci U S A 1981, 78:454-8.

7I. Hasegawa M, Kishino H, Yano T: Dating of the human-ape splitting by a molecular clock of mitochondrial DNA. J Mol Evol 1985, 22:160-174.

72. Strimmer K, von Haeseler A: Likelihood-mapping: a simple method to visualize phylogenetic content of a sequence alignment. Proc Natl Acad Sci USA 1997, 94:68I5-9.

73. Schmidt HA, Strimmer K, Vingron M, von Haeseler A: TREE-PUZZLE: a maximum likelihood phylogenetic analysis using quartets and parallel computing. Bioinformatics 2002, I 8:502-504.

74. Robinson-Rechavi M, Huchon D: RRTree: relative-rate tests between groups of sequences on a phylogenetic tree. Bioinformatics 2000, 16:296-7.

75. Kimura M: A simple method for estimating evolutionary rates of base substitutions through comparative studies of nucleotide sequences. J Mol Evol 1980, 16: I I I-20.

76. Sanderson MJ: Estimating absolute rates of molecular evolution and divergence times: a penalized likelihood approach. Mol Biol Evol 2002, 19:101-109.

77. Maddison WP, Maddison DR: Mesquite: A modular system for evolutionary analysis. Book Mesquite: A modular system for evolutionary analysis, I.06 ed. City 2005 [http://mesquiteproject.org].

78. Pinton $A$, Fara $E$, Otero $O$ : Spine anatomy reveals the diversity of catfish through time: a case study of Synodontis(Siluriformes). Naturwissenschaften 2006, 93:22-6.

Publish with Biomed Central and every scientist can read your work free of charge

"BioMed Central will be the most significant development for disseminating the results of biomedical research in our lifetime. "

Sir Paul Nurse, Cancer Research UK

Your research papers will be:

- available free of charge to the entire biomedical community

- peer reviewed and published immediately upon acceptance

- cited in PubMed and archived on PubMed Central

- yours - you keep the copyright
BioMedcentral 